\title{
Sagittal Lip Positions in Different Skeletal Malocclusions of Nalgonda Population: A Cephalometric Study
}

\author{
S. Vasu Murthy, Praveen Kumar Neela, Pavan Kumar Mamillapalli, M. Shivaprasad, \\ Sreekanth Keesara \\ Department of Orthodontics, Kamineni Institute of Dental Sciences, Narketpally, Nalgonda, Telangana, India.
}

Email for correspondence: praveenneela@yahoo.com

\begin{abstract}
Context: Lip position has become one of the most important soft-tissue analyses as it influences the occlusion, tooth stability, and facial esthetics. Sagittal lip position may vary in different skeletal malocclusions which can be evaluated by various reference lines. Aims and Objectives: The aims of this study were to compare the sagittal lip positions in different skeletal malocclusions in Nalgonda population and with other reported populations. Materials and Methods: The sample consisted of 180 (90 males and 90 females) adult subjects from Nalgonda, population visiting Kamineni Institute of Dental Sciences and Hospital. The age range of the sample chosen was between 18 to 26 years. Lateral cephalometric radiographs of subjects were taken in natural head position. Radiographs were manually traced and five reference lines such as Sushner, Steiner, Burstone, Holdaway, and Ricketts were used. The linear distance between the tip of the lips and the five reference lines were measured. Post hoc Tukey's test was used for comparison of the mean cephalometric values of three skeletal malocclusions. Results: The findings showed a significant difference in the sagittal lip positions in different skeletal malocclusions $(\mathrm{P}<0.05)$. Conclusion: (1) Upper lip (UL) and lower lip (LL) in skeletal Class I group are protrusive than norms on all reference lines. (2) Skeletal Class II group has the most protrusive UL and LL in comparison to skeletal Class I and Class III on all the reference lines. (3) Skeletal Class III group has the most protrusive LL in comparison to skeletal Class II and Class I on all reference lines.
\end{abstract}

Key words: Lip positions, reference lines, skeletal malocclusion

\section{INTRODUCTION}

The soft-tissue analysis has always been an integral part of diagnosis and treatment planning. The nose, lip, and chin are the major components of soft-tissue profile. Various soft-tissue analyses have been developed to help clinicians to quantitatively evaluate the facial morphology. Among this, the position of lips profoundly alters the choice of treatment. Moreover, orthodontic treatment plan

\begin{tabular}{|l|l|}
\hline Quick Response Code & Article Info: \\
\hline doi: 10.5866/2018.10.10015 \\
\hline $\begin{array}{l}\text { Received: 02-01-2018 } \\
\text { Revised: 27-01-2018 } \\
\text { Accepted: 05-02-2018 } \\
\text { Available online: 15-04-2018(www.nacd. } \\
\text { in)( NAD, 2017 - All rights reserved }\end{array}$ \\
\hline
\end{tabular}

can also alter the lip positions. Lip position has become one of the most important soft-tissue analyses as it influences the occlusion, tooth stability, and facial esthetic. ${ }^{[1]}$ The anteroposterior lip position can be evaluated by various reference lines such as Sushner's S2 line, Steiner's S1 line, Burrstone's B line, Ricketts E line, and Holdaway's $\mathrm{H}$ line [Figure 1]. These normative cephalometric values for soft-tissue analyses are based on the studies carried out on Caucasians samples of European American ancestry. Many investigators have proved that there are vast differences among different ethnic and racial groups. They have developed cephalometric standards for different groups and should be treated according to their own characteristics. ${ }^{[2]}$ The adaptation of facial tissues over underlying skeletal discrepancy varies 
among different races and population. This greatly influences the treatment planning and also the success of treatment. Therefore, the objective of the present study is to (1) compare the sagittal lip positions in different skeletal malocclusions and (2) compare the sagittal lip positions in Nalgonda population with other reported populations.

\section{MATERIALS AND METHODS}

The sample consisted of 180 (90 males and 90 females) adult subjects from Nalgonda, population visiting Kamineni Institute of Dental Sciences and Hospital. The age range of the sample chosen was between 18 to 26 years.

\section{Inclusion criteria}

The criteria for selection of each sample are

1. Nalgonda population.

2. Age group of $18-26$ years.

3. Full complement of permanent teeth (not considering $3^{\text {rd }}$ molars).

4. With no gross facial asymmetry.

\section{Exclusion criteria}

1. Previous history of orthodontic treatment, orthognathic, or craniofacial surgery.

2. Subjects with missing permanent teeth except third molars.

3. Previous history of significant medical illness.

\section{Methodology for radiographic study}

The records included a standardized lateral cephalogram of each patient. The cephalometric radiographic apparatus used was Villa Medical System (Rotograph EVO D), a digital panoramic and cephalometric system.

Lateral cephalograms were taken in natural head position [Figure 1]. The horizontal head position was maintained by the cephalostat itself and the teeth were in centric occlusion. The radiographs were exposed at $72 \mathrm{KV} / 8 \mathrm{~mA}$ for $8 \mathrm{~s}$. The film to source distance was $5 \mathrm{ft} 2$, and the distance between the film and patient's midsagittal plane was 6 ".

The cephalograms were traced by affixing transparent $120 \mu$ polyester tracing paper to the cephalometric radiographs with a transparent tape with a $0.3 \mathrm{~mm}$ lead pencil. A single operator performed the tracings in a standardized manner to avoid errors due to interoperator variations. Skeletal malocclusion was classified based on the ANB (A point, nasion $[\mathrm{Ns}], \mathrm{B}$ point) angle and Wits value which indicates the positional relationship of the maxilla and mandible.$^{[3-6]}$ In skeletal Class I malocclusion ANB angle of $0^{\circ}$ to $4^{\circ}$ and Wits value of 0 to $3 \mathrm{~mm}$, in skeletal Class II ANB angle of $>4^{\circ}$ and Wits value of $>-1 \mathrm{~mm}$, in skeletal Class III ANB angle of $<0^{\circ}$ and Wits value of $<-4 \mathrm{~mm}$ were taken as normal values. The patients were categorized into three skeletal malocclusions classes and each skeletal malocclusion class having 30 each male and female patient. The linear distances between the tips of the lips and the five reference lines were measured. When lips were positioned in front of the reference line, they were denoted by positive sign, when behind the reference line, they were denoted by negative sign, and zero when lips were on the reference line.

\section{Soft-tissue landmarks used in the study are}

Soft-tissue Ns - The point of deepest concavity of the soft-tissue contour of the root of the nose.

Pronasale $(\mathrm{Pn})$ - The most prominent point of the nose.

Subnasale (Sn)-The point where the lower border of the nose meets the outer contour of the upper lip (UL).

Labial superius (Ls) - The median point in the upper margin of the upper membranous lip.

Labial inferius $(\mathrm{Li})$ - The median point in the lower margin of the lower membranous lip.

Soft-tissue pogonion (Pos) - The most prominent point on the soft-tissue contour of the chin.

Considering the above landmarks, the Burstone line (B line), Steiner's line (S1 line), Sushner's line (S2 line), Rickets line (E line), and Holdaway line (H line) reference lines were measured with the normal values [Figure 2].

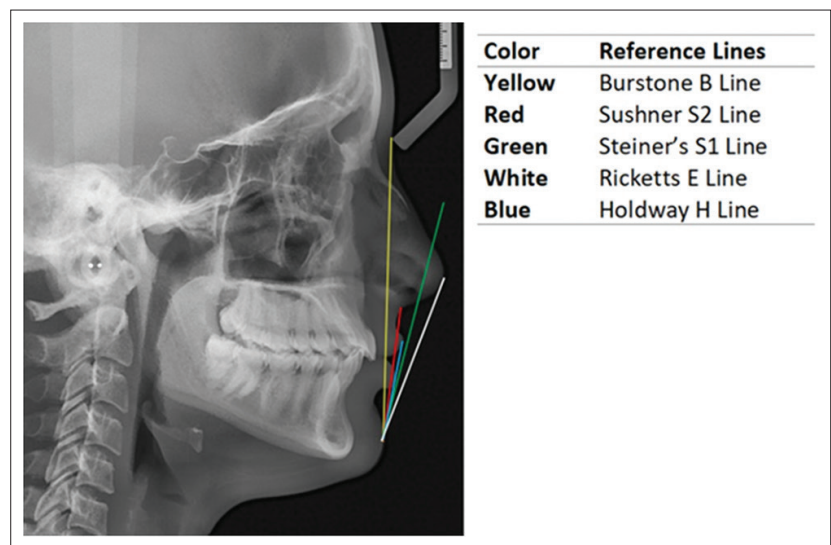

Figure 1: Reference lines on lateral cephalogram 
For Burstone line, normal value for UL is $3.5 \pm$ $1.4 \mathrm{~mm}$; for lower lip (LL) is $2.2 \pm 1.6 \mathrm{~mm}$.

For Steiner's line, lips should touch the reference line.

For Sushner's line, normal value in male is $10.3 \mathrm{~mm}$ for UL $7.8 \mathrm{~mm}$; for LL in females is $8.8 \mathrm{~mm}$ for UL $6.7 \mathrm{~mm}$ for LL

For Rickets line, normal value for $\mathrm{LL}$ is $-2 \mathrm{~mm}$.

For Holdaway line, normal value LL should touch the reference line or line -1 to $-2 \mathrm{~mm}$.

\section{Statistical analysis}

Statistical analysis was done using the Statistical Package for the Social Sciences version 23. Descriptive analysis was carried out for each variable for each subject. Post hoc Tukey's test was used for comparison of the mean cephalometric values of the three skeletal malocclusions. The level of significance for the analysis was set at $\mathrm{P}<0.05$.

\section{RESULTS}

There was a statistical significance between:

- Burstone UL in Class II and III

- Steiner's S1 UL and LL in Class I, II, and III

- Sushner's S2 UL and LL in Class I, II, and III

- Ricketts e line in Class I, II, and III

- Holdaway h line in Class I, II, and III

In Burstone LL, there was no statistical significance in any of the Class I, II, and III [Table 1].

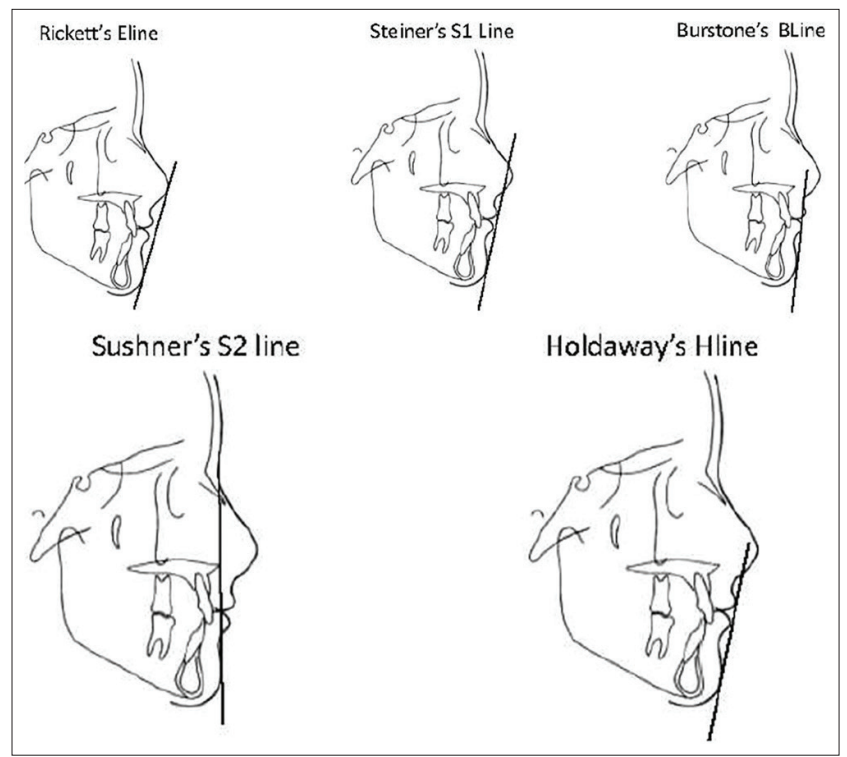

Figure 2: Individual reference lines

\section{Sushner's S2 line}

Skeletal Class I group, S2 line showed more protrusive UL $14.80 \pm 3.02 \mathrm{~mm}$ and LL $9.45 \pm 2.4 \mathrm{~mm}$ than norms given by Sushner UL 8.8-10.3 $\mathrm{mm}$ and LL 6.7-7.8 mm. In skeletal Class II group, ULs 17.5 $\pm 2.73 \mathrm{~mm}$ were more protruded and LLs $10.5 \pm$ $2.99 \mathrm{~mm}$ were protrusive than skeletal Class I and Class III groups. In the case of skeletal Class III group, the ULs $11.42 \pm 1.95 \mathrm{~mm}$ and LLs $8.88 \pm$ $2.30 \mathrm{~mm}$ were retrusive in comparison to Class I and Class II [Table 2].

\section{Burstone's B line}

When using B line, the UL $7.58 \pm 2.00 \mathrm{~mm}$ and the $\mathrm{LL} 5.50 \pm 2.31 \mathrm{~mm}$ in skeletal Class I group were protrusive than given by Burstone UL 3.5 to 4.5 and LL 1 to 3 . In the case of skeletal Class II group, UL $8.28 \pm 1.87 \mathrm{~mm}$ was more protrusive and LL $3.01 \pm 2.25 \mathrm{~mm}$ was retrusive than skeletal Class I. Skeletal Class III group, UL 6.63 \pm 2.25 and LL 2.91 $\pm 2.53 \mathrm{~mm}$ were retruded than Class I and Class II [Table 2].

\section{Steiner's S1 line}

In skeletal Class I group, S1 line showed protrusive UL $3.46 \pm 1.53 \mathrm{~mm}$ and $\mathrm{LL} 5.13 \pm$ $2.32 \mathrm{~mm}$ than norms given by Steiner. In skeletal Class II group, UL $4.59 \pm 3.66 \mathrm{~mm}$ and LL $5.41 \pm$ $2.58 \mathrm{~mm}$ were more protrusive than in skeletal Class I and Class III groups. In skeletal Class III,

\begin{tabular}{|c|c|c|c|c|}
\hline $\begin{array}{l}\text { Reference } \\
\text { lines }\end{array}$ & Lips & Class I & Class II & $\begin{array}{c}\text { Class } \\
\text { III }\end{array}$ \\
\hline $\begin{array}{l}\text { Burstone } B \\
\text { line }\end{array}$ & $\begin{array}{l}\text { Upper } \\
\text { lip }\end{array}$ & 0.448 & 0.003 & 0.049 \\
\hline $\begin{array}{l}\text { Burstone } B \\
\text { line }\end{array}$ & $\begin{array}{l}\text { Lower } \\
\text { lip }\end{array}$ & 1.000 & 1.000 & 1.000 \\
\hline Steiner S1 & $\begin{array}{l}\text { Upper } \\
\text { lip }\end{array}$ & 0.000 & 0.022 & 0.000 \\
\hline Steiner S1 & $\begin{array}{l}\text { Lower } \\
\text { lip }\end{array}$ & 0.000 & 0.000 & 0.002 \\
\hline $\begin{array}{l}\text { Sushner's S2 } \\
\text { line }\end{array}$ & $\begin{array}{l}\text { upper } \\
\text { lip }\end{array}$ & 0.000 & 0.000 & 0.00 \\
\hline $\begin{array}{l}\text { Sushner's S2 } \\
\text { line }\end{array}$ & $\begin{array}{l}\text { Lower } \\
\text { lip }\end{array}$ & 0.054 & 0.054 & 0.000 \\
\hline Rickets E line & $\begin{array}{l}\text { Lower } \\
\text { lip }\end{array}$ & 0.000 & 0.028 & 0.000 \\
\hline $\begin{array}{l}\text { Holdaway } H \\
\text { line }\end{array}$ & $\begin{array}{l}\text { Lower } \\
\text { lip }\end{array}$ & 0.000 & 0.000 & 0.000 \\
\hline
\end{tabular}




\begin{tabular}{|c|c|c|c|c|c|c|c|c|}
\hline \multirow[t]{2}{*}{ Reference lines } & \multirow[t]{2}{*}{ Lips } & \multirow[t]{2}{*}{ Gender } & \multicolumn{2}{|c|}{ Class I } & \multicolumn{2}{|c|}{ Class II } & \multicolumn{2}{|c|}{ Class III } \\
\hline & & & Value & SD & Value & SD & Value & SD \\
\hline \multirow[t]{2}{*}{ Burstone } & \multirow[t]{2}{*}{ Upper lip } & Males & 7.93 & 2.13 & 8.73 & 2.1 & 6.90 & 2.15 \\
\hline & & Females & 7.23 & 1.92 & 7.83 & 1.39 & 6.37 & 2.0 \\
\hline \multirow[t]{2}{*}{ Burstone } & \multirow[t]{2}{*}{ Lower lip } & Males & 6.10 & 3.25 & 6.33 & 2.46 & 5.93 & 2.57 \\
\hline & & Females & 4.90 & 2.17 & 8.17 & 3.56 & 6.20 & 3.26 \\
\hline \multirow[t]{2}{*}{ Steiner $S 1$} & \multirow[t]{2}{*}{ Upper lip } & Males & 3.80 & 2.69 & 5.02 & 2.72 & 1.26 & 2.74 \\
\hline & & Females & 3.13 & 1.69 & 4.17 & 2.08 & 1.50 & 2.93 \\
\hline \multirow[t]{2}{*}{ Steiner $S 1$} & \multirow[t]{2}{*}{ Lower lip } & Males & 5.40 & 3.26 & 5.83 & 2.99 & 2.35 & 2.46 \\
\hline & & Females & 4.87 & 2.50 & 5.0 & 2.69 & 2.73 & 3.36 \\
\hline \multirow[t]{2}{*}{ Sushner S2 } & \multirow[t]{2}{*}{ Upper lip } & Males & 15.7 & 3.47 & 18.23 & 3.39 & 11.6 & 3.46 \\
\hline & & Females & 14.01 & 2.87 & 16.77 & 2.67 & 11.27 & 4.30 \\
\hline \multirow[t]{2}{*}{ Sushner S2 } & \multirow[t]{2}{*}{ Lower lip } & Males & 9.70 & 3.51 & 10.4 & 3.58 & 8.77 & 2.64 \\
\hline & & Females & 9.20 & 2.28 & 10.6 & 2.95 & 9.0 & 3.93 \\
\hline \multirow[t]{2}{*}{ Rickets $E$ line } & \multirow[t]{2}{*}{ Lower lip } & Males & 2.85 & 3.33 & 3.7 & 3.13 & 0.89 & 3.01 \\
\hline & & Females & 3.13 & 2.59 & 4.37 & 2.54 & 0.27 & 4.72 \\
\hline \multirow[t]{2}{*}{ Holdaway $H$ line } & \multirow[t]{2}{*}{ Lower lip } & Males & 3.43 & 3.46 & 3.20 & 2.93 & 2.23 & 3.13 \\
\hline & & Females & 2.7 & 2.10 & 4.6 & 3.52 & 2.93 & 2.19 \\
\hline
\end{tabular}

SD: Standard deviation

the UL $1.38 \pm 2.40 \mathrm{~mm}$ and LL $2.54 \pm 2.19 \mathrm{~mm}$ were retrusive in comparison to skeletal Class I and Class II [Table 2].

\section{Ricketts E line}

In skeletal Class I group, both LL $2.99 \pm 2.09 \mathrm{~mm}$ were within the range of norms provided by Ricketts E line of LL $-2+2$. In skeletal Class II group, LL $4.03 \pm 2.51 \mathrm{~mm}$ was more protruded than in skeletal Class I and Class III groups. In the case of skeletal Class III, LLs $0.58 \pm 2.41 \mathrm{~mm}$ were retrusive in comparison to Class I and Class II [Table 2].

\section{Holdaway's $\mathrm{H}$ line}

In skeletal Class I, the LL $(3.05 \pm 2.36 \mathrm{~mm})$ in skeletal Class I was protrusive than the reference norm of $\mathrm{H}$ line $\mathrm{LL}$ of -1 to $+2 \mathrm{~mm}$. In skeletal Class II, LL $3.9 \pm 2.36 \mathrm{~mm}$ was protrusive than the Class I and Class III. LLs in skeletal Class III, $2.58 \pm 2.16 \mathrm{~mm}$ were retrusive than in skeletal Class I and Class II [Table 2].

\section{DISCUSSION}

This study is designed to determine the sagittal lip positions in relation to the five reference lines in three different skeletal malocclusions. The sample included adult subjects of age 18-26 years as the majority of facial growth is usually completed by 16
17 years of age. ${ }^{[7]}$ The subjects were selected from those individuals who had a lateral cephalometric radiograph taken for diagnosis purposes. Assessment based on pleasing profiles and satisfactory, occlusion is subjective and introduces biases. Furthermore, they do not represent the randomized representation of the particular population. Hence, it is important to analyze these reference lines in different skeletal malocclusions to determine which reference line is more reliable in each skeletal malocclusion. Erbay et al. found that soft-tissue analysis differs according to the population. Every race has its one nose and chin characteristics. ${ }^{[8]}$ Sushner developed his norms for black population. Ricketts norms are applied to Caucasians and not to all ethical and racial groups. Thus, using soft-tissue norms of one population would be unreliable in diagnosis and treatment planning for another population. It would be helpful to assess the reliability of these reference lines in Nalgonda population. In this study, five reference lines were used because these reference lines are most frequently used during diagnosis and treatment.

\section{Comparison of skeletal Class I with Caucasian norms and other population}

The present study revealed that both the UL and the LL in skeletal Class I were more protrusive 
than normative values of Ricketts, Burstone, Sushne, Steiner, and Holdaway lines. This is due to the fact that the craniofacial morphology between individuals with Telangana and Caucasian ancestry shows significant difference. Telangana samples exhibited significantly protrusive UL and LL than Caucasians. Sachan et al. conducted a study in north Indian population and found out that the mean LL to $\mathrm{H}$ line was $1.10 \pm 1.96$ in men. ${ }^{[9]}$ Upadhyaya et al. conducted a study in western Uttar Pradesh population and found out that the mean UL to $\mathrm{S} 1$ line is $1.54 \mathrm{~mm}$ and LL to $\mathrm{S} 1$ line $1.61 \mathrm{~mm} \cdot{ }^{[10]}$ Purushotaman et al. conducted a study in Malabar population and found that the mean LL to E line was $3.43 \pm 1.07$ in females and $3.5 \pm 1.30$ in males and LL to $\mathrm{H}$ line was $1.31 \pm 0.8$ in females and in males $1.54 \pm 1.20 \mathrm{~mm} \cdot{ }^{[11]}$ Lew et al. compared $\mathrm{H}$ angle between Chinese and Caucasians and found that the Chinese samples had more protrusive lips, a more anteriorly placed maxilla than Caucasian and lips that were not harmonious with the $\mathrm{H}$ line. ${ }^{[12]}$ Adult Nigerian population showed more protrusive UL and LL than the normative values reported for Caucasians. ${ }^{[13]}$ The Korean population is also reported to have greater degree of UL and LL protrusion when compared to a European American sample. ${ }^{[14]}$ Craniofacial cephalometric analysis of Bangladeshi females had significantly more protruded lip positions when compared with the Caucasian group. When compared with the Japanese females, Bangladeshi females had significantly less protrusion. ${ }^{[15]}$ In the present study, there was an overall protrusion in all the reference lines compared to Korean, Chinese, Caucasian, and Bangladeshi population.

These variations in lip position of different populations reinforce the fact that soft-tissue features are specific for each given race and ethnicity. Moreover, also this comparison with Caucasian and other population group must be interpreted with caution because of variations in sample sizes and also differences in the population.

\section{Comparison among different skeletal classes}

Overall, it was observed that in the case of skeletal Class II group, all the reference lines showed the ULs and LLs are protrusive compared to skeletal Class I and Class III groups. In the case of skeletal Class III group, ULs and LLs were retrusive than in skeletal Class I and Class II. While in Ricketts E line, LL of Class III was more retrusive compared to baseline. While in females LL of Burstone, Sushners, and Holdaway, mean values were comparatively more in Class II malocclusion compared to males. UL sagittal position can be better assessed by S2 line in different skeletal malocclusions. In the case of LL sagittal position, $\mathrm{H}$ line is the line of choice. This finding may be due to the fact that S2 line is close to skeletal structure and not influenced by the nose. As the LL is closely influenced by the UL position, $\mathrm{H}$ line can be considered as the best line in assessing LL position. In the present study, statistically significant difference for all the reference lines in assessing sagittal lip position among all skeletal classes was not observed. The reason behind could be variation in dentoalveolar structures, especially the upper and lower incisors. There was no statistical significance in Burstone LL in any of the Class I, II, and III.

\section{Factors affecting lip position}

Cephalometric measurements of face in terms of esthetics can be difficult and misleading due to various factors. Several studies had shown that soft- and hard-tissue changes are highly correlated. Altemus, in his study, found that facial balance and harmony are often in compromised or compensated in relationship with skeletal, dental, and soft-tissue component of the face. ${ }^{[16]}$ Dental factors, such as the inclination of upper and lower anterior relative to the palatal and mandibular plane, respectively, affect the lip positions. The movement of the cervical point of the upper incisor or the incisor retraction with translator movement greatly influenced changes in the UL position in the horizontal plane.${ }^{[17]}$ As many of the reference lines used for facial analysis pass through the nose and chin, growth and morphology of the nose and chin would greatly affect the lip position. Ricketts $\mathrm{E}$ line should be read in relation to the nose and chin. Ricketts $\mathrm{E}$ line is influenced by the growth of the nose. Whereas Steiner's S1 line eliminates half of the changes in integument profile due to the growth of the nose. Nasal growth is eliminated in $\mathrm{H}$ line, B line, and Sushner line. The relation of the lip with the $\mathrm{B}$ line depends on the thickness of the lip and correct position of lips. When lips are equally thick, B line is more reliable. Both chin and nasal position influence the horizontal lip position. ${ }^{[18-20]}$ In Turkish adult, significant differences in soft-tissue thickness among skeletal malocclusions were observed for the Ls, stomion, and Li sites. Moreover, soft-tissue thickness at all sites was greater in men than in women. ${ }^{[21]}$ The two main treatment approaches extraction and non-extraction 
have been highly controversial issues, and it mainly depends on the patient profile. This controversy becomes even greater when dealing with borderline cases. When planning treatment for Class I cases, the extraction decision mainly depends on lower anterior crowding, LL to E line, upper crowding, and overjet. These four key orthodontic measurements will possibly vary if we take different populations. ${ }^{[22]}$

A large sample can be considered in the future studies as it is a better representative of the population. Conventional cephalometric approach encounters several limitations. Conebeam computed tomography offers the possibility of accurate localization and quantification of even minor asymmetries without distortion, and hence, much more precise cephalometric analyses.

\section{CONCLUSION}

- UL and LL in skeletal Class I group are protrusive than norms on all reference lines.

- Skeletal Class II group has the most protrusive UL and LL in comparison to skeletal Class I and Class III on all the reference lines.

- Skeletal Class III group has the most protrusive LL in comparison to skeletal Class II and Class I on all the reference lines

- In the case of skeletal Class I and Class II, S2 line is the line of choice to judge the sagittal position of lips in profile analysis.

- In the case of skeletal Class III, B line is the line of choice to judge the sagittal position of lips in profile analysis.

\section{REFERENCES}

1. Burstone CJ. Lip posture and its significance in treatment planning. Am J Orthod 1967;53:262-84.

2. Basciftci FA, Uysal T, Buyukerkmen A. Determination of Holdaway soft tissue norms in Anatolian Turkish adults. Am J Orthod Dentofacial Orthop 2003;123:395-400.

3. Steiner CC. The use of cephalometrics as an aid to planning and assessing orthodontic treatment: Report of a case. Am J Orthod 1960;46:721-36.

4. Taylor CM. Changes in the relationship of nasion, point A, and point $\mathrm{B}$ and the effect upon ANB. Am J Orthod 1969;56:143-63.

5. Jacobson A. The "wits" appraisal of jaw disharmony. Am J Orthod 1975;67:125-38.

6. Jacobson A. Application of the "wits" appraisal. Am J Orthod 1976;70:179-89.
7. Oliver ML. W and H orthodontic notes. J Orthod 2000;28:1

8. Elif F, Erbay CM, Erbay SK. Soft tissue profile in Anatolian Turkish adults: Part I. Evaluation of horizontal lip position using different soft tissue analyses. Am J Orthod Dentofacial Orthop 2002;121:57-64.

9. Sachan A, Srivastav A, Chaturvedi TP. Soft-tissue cephalometric norms in a north Indian ethnic population. J Orthod Sci 2012;1:92-7.

10. Upadhyay JS, Maheshwari S, Verma SK, Zahid SN. Soft tissue cephalometric analysis applied to regional Indian population. Natl J Maxillofac Surg 2013;4:159-66.

11. Purushothaman B, Raveendran R, Sundareswaran S, Harindranathan M. Soft tissue cephalometric norms of Malabar population in northern Kerala: An epidemiologic study. Indian Orthod Soc 2012;46:65-9.

12. Lew KK. Cephalometric ideals in Chinese, Malay and Indian ethnic groups. Asian J Aesthet Dent 1994;2:35-8.

13. IkennaIsiekweG,OlatokunboDaCostaO,Chukwudi Isiekwe M A cephalometric investigation of horizontal lip position in adult Nigerians. J Orthod 2012;39:160-9.

14. Hwang HS, Kim WS, McNamara JA. Ethnic differences in the soft tissue profile of Korean and European American adults with normal occlusion and well balanced faces. Angle Orthod 2002;72:72-80.

15. Ahsan A, Yamaki M, Hossain Z, Saito I. Craniofacial cephalometric analysis of Bangladeshi and Japanese adults with normal occlusion and balanced faces: A comparative study. J Orthod Sci 2013;2:7-15.

16. Altemus LA. Cephalofacial relationships. Angle Orthod 1968;38:175-84.

17. Ramos AL, Sakima MT, Pinto Ados S, Bowman SJ. Upper lip changes correlated to maxillary incisor retraction - a metallic implant study. Angle Orthod 2005;75:499-505.

18. Hsu BS. Comparisons of the five analytic reference lines of the horizontal lip position: their consistency and sensitivity. Am J Orthod Dentofacial Orthop 1993;104:355-60.

19. Oh HS, Korn EL, Zhang X, Liu Y, Xu T, Boyd R, et al. Correlations between cephalometric and photographic measurements of facial attractiveness in Chinese and US patients after orthodontic treatment. Am J Orthod Dentofacial Orthop 2009;136:762.e1-14.

20. Cala L, Spalj S, Slaj M, Lapter MV, Slaj M. Facial profile preferences: Differences in the perception of children with and without orthodontic history. Am J Orthod Dentofacial Orthop 2010;138:442-50

21. Kamak H, Celikoglu M. Facial soft tissue thickness among skeletal malocclusions: is there a difference? Korean J Orthod 2012;42:23-31.

22. Konstantonis D, Anthopoulou C, Makou M. Extraction decision and identification of treatment predictors in Class I malocclusions. Prog Orthod 2013;14:47. 